\title{
PHD TRAINING IN SIMULATION: NATCOR
}

\author{
Michael Pidd \\ Lancaster University Management School \\ Department of Management Science \\ Lancaster, LA1 4YX, UK
}

\author{
Stewart Robinson \\ Ruth Davies \\ Kathryn Hoad \\ University of Warwick \\ Warwick University Business School \\ Coventry, CV4 7AL, UK
}

\author{
Russell Cheng \\ University of Southampton \\ Faculty of Mathematical Studies \\ Highfield, Southampton, SO17 1BJ, UK
}

\begin{abstract}
To provide a broader education for Operational Research $\mathrm{PhD}$ students in the UK, the Engineering and Physical Sciences Research Council funds the National Taught Course Centre for Operational Research (NATCOR). This is an initiative led by six UK universities and includes a one-week, residential simulation module taught for the first time in July 2009. We describe the background to NATCOR, summarize its content and reflect on its further development.
\end{abstract}

\section{PHD TRAINING IN THE UK}

Though there are exceptions, $\mathrm{PhD}$ training in the UK is mainly based on an apprenticeship model in which the $\mathrm{PhD}$ candidate is assigned one or more supervisors with whom (s)he works throughout the period of $\mathrm{PhD}$ registration. In many cases, the candidate is required to present an outline research proposal even before registration, though more often this develops during their first year. In most universities, $\mathrm{PhD}$ candidates are formally regarded as $\mathrm{PhD}$ students; that is, as postgraduates alongside others, taking taught courses, typically at Masters level. Most Masters students in the UK are registered on taught courses lasting the full-time equivalent of 12 months, on which they take assessed modules in which they must reach at least a pass standard. Though $\mathrm{PhD}$ candidates are encouraged to attend available taught modules, usually in their home university, these courses are not usually assessed requirements for the award of a PhD. However changes are now being introduced by some universities to ensure a more formal assessment of a range of aspects considered important in $\mathrm{PhD}$ training. These include delivery of oral presentations, attendance of seminars and conferences, assisting in teaching and also attendance of taught modules deemed important but not already familiar to the candidate.

Most $\mathrm{PhD}$ programmes in the UK assume that full-time candidates will submit their completed dissertation within 4 years. There is still an unspoken view that the norm ought to be doing so in 3 years; though doing so is increasingly rare. PhD students pay fees, though these may be paid by scholarships and bursaries of which there are more in some subjects than others. The UK Research Councils, which fund individual research projects and programmes, also provide $\mathrm{PhD}$ funding that covers fees and living costs 


\section{Pidd, Robinson, Davies, Hoad and Cheng}

for some students. Though no official figures are available, our impression is that Research Councils fund only a small minority of $\mathrm{PhD}$ students studying in areas related to computer simulation. Until recently, most Research Council support lasted just 3 years, furthering the impression that completion in 3 years is the norm. In many cases, this support has now been extended to $3 \frac{1}{2}$ years, though this does not cover a taught Masters degree to prepare candidates for $\mathrm{PhD}$ work.

There is an increasing use of $\mathrm{PhD}$ students as Teaching Assistants, which enables them to earn their keep, but distracts them from their $\mathrm{PhD}$ research, lengthening the time they take to complete. Universities in which too few students submit their $\mathrm{PhD}$ dissertation within 4 years may be penalized by university funding bodies. There is thus great pressure on both PhD candidates and their departments to see that they complete in under 4 years.

In summary, most $\mathrm{PhD}$ training in the $\mathrm{UK}$ is different from that in some countries. The main differences are:

- Normally there is no formally assessed set of taught modules that must be completed as part of a PhD.

- Full-time PhD candidates are assumed to complete their work in 4 years or less.

- $\mathrm{PhD}$ candidates are regarded as students and not as junior faculty.

- Most PhD students work under the supervision of one or two faculty throughout their $\mathrm{PhD}$ period and these supervisors are often assigned when the student arrives at the university.

\section{INTERNATIONAL REVIEW OF RESEARCH IN OR}

In 2004, the Engineering and Physical Sciences Research Council (EPSRC), which is a major funder of research and $\mathrm{PhD}$ training in Operational Research (OR), conducted an international review of the status of UK research. Around the same time it conducted similar reviews of the various subjects within its domain. An international panel met representatives from a range of universities and user groups and used available metrics to assess the research status of OR. In general, UK OR was regarded as being in excellent health, with much high quality, innovative research. However, the panel expressed concern about the breadth and depth of UK PhD training in OR. As a response to this, six UK universities with significant numbers of OR PhD students (Brunel, Cardiff, Lancaster, Nottingham, Southampton and Warwick) collaborated in a bid for EPSRC funding with the support of the UK OR Society. This bid was successful and led to funding of about $£ 250,000$ for the creation of NATCOR (the National Taught Course Centre in Operational Research).

\section{NATCOR}

NATCOR provides a series of residential taught modules on topics of major importance in mathematical OR. During 2009-2011 these include:

- Heuristics and approximation algorithms

- Convex optimization

- Data envelopment analysis

- Stochastic modeling

- Simulation

- Combinatorial optimization

Students whose $\mathrm{PhD}$ work is funded by EPSRC attend free of charge and a small fee is levied on others who are not funded by EPSRC and this is usually paid by their departments. Though many students are from the six collaborating universities, attendees come from many other universities and include some from outside the UK.

This set of residential modules was devised to bring $\mathrm{PhD}$ students up to speed in a broader range of subjects than was normal in the past. This is obviously useful for those $\mathrm{PhD}$ candidates who will enter academic posts and will need to teach subjects other than that of their $\mathrm{PhD}$. It also exposes them to other approaches than ones with which they are familiar and can greatly broaden their work in the $\mathrm{PhD}$ itself. The residential aspect also helps create a national community of OR $\mathrm{PhD}$ students as they spend time to- 


\section{Pidd, Robinson, Davies, Hoad and Cheng}

gether, meet up from time to time on the modules and keep in touch in many different ways. Each module is assessed, though it is left to the university with which a $\mathrm{PhD}$ student is registered to decide how to use the marks obtained. In most cases, the module assessments do not formally count toward the $\mathrm{PhD}$. More details of the NATCOR programme, including views from the students who attend, can be found at their website (NATCOR 2010).

\section{THE NATCOR SIMULATION MODULE}

Though a single university takes the lead in organizing a module it is taught by a team from several universities so as to reduce the risk of any one university dominating proceedings. This is important if the programme is to be a true collaboration between the universities. The simulation module is organized by Stewart Robinson of Warwick University. It has been taught once so far, in July 2009. It was attended by 84 students and its tutors came from Lancaster, Southampton and Warwick Universities, with a further contribution from an experienced simulation practitioner. The aim of the course was to provide an understanding of the mathematical and statistical principles of stochastic simulation modeling. The material available to students before the module told them:

"Simulation is one of the most widely used operational research techniques. It involves the development of an imitation on a computer of the system under study, followed by experimentation to understand and investigate improvements to the system. This course provides an understanding of simulation, with a focus on the mathematical and statistical principles of stochastic simulation modeling. The main technique of interest is discrete-event simulation, although other simulation techniques will be introduced."

Specifically, the module aimed to enable $\mathrm{PhD}$ students to:

- Understand the basic principles of simulation and performing simulation studies.

- Understand the basic theory of simulation analysis including input data analysis, experimentation and output analysis.

- To be aware of the strengths and limitations of the approaches covered.

- In addition, by the end of the module, the students were expected to:

- Be able to develop and use a simulation model for a given problem situation.

- Be able to evaluate the quality of a simulation analysis.

- Be familiar with the use of a simulation software package (SIMUL8).

- Be familiar with the use of statistical analysis software (e.g. Excel, Minitab, SPSS).

Handouts were provided for each section of the module. In addition, the students were recommended to use Krzanowski (1998), Makridakis, Wheelwright and Hyndman (1998), Pidd (2005) and Robinson (2004) for further reading; plus, of course, the Winter Simulation Conference Proceedings. Since some of the attendees were undertaking $\mathrm{PhD}$ research in simulation whereas others had only a passing interest, it was important that the material covered was taught in a way that was interesting and engaging, but at a high enough level to enable students to read the research literature.

The simulation module began on a Monday lunch-time and ended on a Friday lunch-time to enable attendees to travel to and from Warwick University where the module was held. It included computerbased workshops and formal lectures. Some evening work was needed, but most evenings were devoted to networking/socializing. The material covered was divided into the 5 sections shown in Table 1 .

An assessment exercise was given to the students halfway through the course. This involved using a pre-developed simulation model (in SIMUL8) for experimentation. The students were asked to investigate the warm-up, run-length and replications requirements with the model and to perform a comparison of a series of scenarios using the methods taught on the course. Working in small groups, the students wrote a short report on their work. This was handed in first thing on Friday morning and feedback was provided at the end of the course. 
Table 1: Outline of the NATCOR simulation module

\begin{tabular}{|c|c|c|}
\hline \multirow{6}{*}{ 1: Principles of } & Introduction to simulation methods & \multirow[t]{4}{*}{ Mike Pidd } \\
\hline & Generating random variates & \\
\hline & Computing aspects of simulation & \\
\hline & Distributed simulation & \\
\hline & Simulation studies and the simulation modeling life cycle & \multirow[t]{2}{*}{ Stewart Robinson } \\
\hline & Model validation & \\
\hline \multirow{2}{*}{$\begin{array}{l}\text { 2: Variance re- } \\
\text { duction }\end{array}$} & Random number generation & \multirow{2}{*}{$\begin{array}{l}\text { Ruth Davies and } \\
\text { Katy Hoad }\end{array}$} \\
\hline & Variance reduction methods & \\
\hline $\begin{array}{l}\text { 3: Simulation in } \\
\text { action }\end{array}$ & Simulation in action & $\begin{array}{l}\text { Shane Kite, Saker } \\
\text { Solutions Ltd }\end{array}$ \\
\hline \multirow{2}{*}{$\begin{array}{l}\text { 4: Introduction to } \\
\text { output analysis }\end{array}$} & Analysis of a single scenario - obtaining accurate results & \multirow[t]{2}{*}{ Stewart Robinson } \\
\hline & Basics of comparing multiple scenarios & \\
\hline \multirow{5}{*}{$\begin{array}{l}\text { 5: Experimental } \\
\text { design \& anal- } \\
\text { ysis }\end{array}$} & Time series analysis & \multirow[t]{5}{*}{ Russell Cheng } \\
\hline & Experimental design & \\
\hline & Metamodeling & \\
\hline & Simulation optimization & \\
\hline & Bootstrapping (for input data as well) & \\
\hline
\end{tabular}

\section{REFLECTIONS IN OUR NATCOR EXPERIENCE}

At the end of the week the students completed a questionnaire which asked for their reflections on the course. Questions sought feedback on a wide range of topics from the standard of accommodation to the delivery of the course content. The quantitative scores showed a good level of satisfaction with the course and many students said they would recommend the course to other $\mathrm{PhD}$ students in the future.

Space was provided for written comments which provided some interesting perspectives on the course. One of the key benefits of the week was seen to be the networking opportunities it provided with $\mathrm{PhD}$ students from other institutions. Most of the students could see the relevance of the course to their own $\mathrm{PhD}$ research and they appreciated the breadth of topics covered in the week. Some, however, felt that too much ground was covered in the time available. The students also found the inclusion of case studies and discussion on practical applications helpful; although some would have preferred more emphasis on these aspects.

A clear difficulty in running the course was the range of knowledge of simulation that the students had prior to attending the week. Some had previously studied simulation courses (largely as part of a Masters programme before registering for a $\mathrm{PhD}$ ), a handful were using simulation extensively in their $\mathrm{PhD}$ research, and the remainder had little or no knowledge of simulation. This lead to some dissatisfaction with the level of the content in the course, with some asking for more depth and others suggesting less. Without splitting the course into two or more groups, such issues are almost impossible to address.

From the teachers' perspective the NATCOR simulation course provided an opportunity to teach simulation at some depth to those who may use it as part of their research. We were also able to meet those who will be the future researchers in OR and some in simulation. We look forward to running the course again in July 2011, with some changes in the light of comments received in 2009.

\section{REFERENCES}

Krzanowski, W.J. 1998. An introduction to statistical modelling. London: Arnold

Makridakis, S., S.C. Wheelwright, and R.J. Hyndman. 1998. Forecasting. Methods and applications. New York: Wiley. 
NATCOR 2010. NATCOR - A National Taught Course Centre for Operational Research. Available via: $<$ http://www. natcor.ac.uk> [accessed October 13, 2010].

Pidd, M. 2005. Computer simulation in management science. 5th ed. Chichester, UK: Wiley.

Robinson, S. 2004. Simulation: The practice of model development and use. Chichester, UK: Wiley.

\section{AUTHOR BIOGRAPHIES}

MICHAEL PIDD is Professor of Management Science and Head of the Department of Management Science at Lancaster University Management School. He is known for his writings on simulation modeling, including the books Computer Simulation in Management Science and Tools for Thinking: Modelling in Management Science, both of which have been in print for many years. His current research interests include simulation modeling in healthcare, technical developments in simulation modeling methodology and performance measurement in public services. He is a past-President of the UK Operational Research Society. His email address is $<\mathrm{m}$.piddelancaster.ac.uk $>$ and his personal homepage is at <http://www.lancs.ac.uk/staff/smamp >.

STEWART ROBINSON is a Professor of Operational Research at Warwick Business School and Associate Dean for Specialist Masters Programmes. He holds a BSc and PhD in Management Science from Lancaster University. Previously employed in simulation consultancy, he supported the use of simulation in companies throughout Europe and the rest of the world. He is author/co-author of four books on simulation. His research focuses on the practice of simulation model development and use. Key areas of interest are conceptual modeling, model validation, output analysis and modeling human factors in simulation models. His email address is <stewart.robinson@warwick.ac.uk> and his Web address is <http: //www. btinternet.com/ stewart.robinsonl/sr.htm>.

RUTH DAVIES is a Professor of Operational Research in Warwick Business School, University of Warwick. She was previously at the University of Southampton. Her expertise is in modeling health systems, using simulation to describe the interaction between the parts in order to evaluate current and potential future policies. Over the past few years she has run several substantial projects funded by the Department of Health, in order to advise on policy on: the prevention, treatment and need for resources for coronary heart disease, gastric cancer, end-stage renal failure and diabetes. Her email address is <ruth.davies@wbs.ac.uk>.

KATY HOAD is an Assistant Professor in the Operational Research and Management Sciences Group at Warwick Business School, University of Warwick. She holds a BSc in Mathematics, MSc in Statistics and $\mathrm{PhD}$ in Operational Research from Southampton University. Her research focuses on simulation output analysis and the mathematical modeling of diseases. Her email address is <kathryn.hoadewbs.ac.uk>.

RUSSELL CHENG is Emeritus Professor of Operational Research at the University of Southampton. He has an M.A. and the Diploma in Mathematical Statistics from Cambridge University, England. He obtained his Ph.D. from Bath University. He is a former Chairman of the U.K. Simulation Society, a Fellow of the Royal Statistical Society and a Member of the Operational Research Society. His research interests include: design and analysis of simulation experiments and parametric estimation methods. He was a Joint Editor of the IMA Journal of Management Mathematics. His email and web addresses are $<$ R.C.H.Chengesoton.ac.uk> and <http: //www.personal. soton.ac.uk/rchc>. 